\title{
PENINGKATAN KUALITAS KESEHATAN MASYARAKAT UNTUK PENCEGAHAN COVID-19
}

\author{
Mochamad Imron Azami1*, M. Agus Saifuddin², Ardhi GP², Ayu Rizki Wulandari², M. \\ Naufal Syahriza' ${ }^{2}$, Muhammad Abdussalam Afif ${ }^{2}$, Fina Aimmatur Rifqi ${ }^{3}$, Siti Aisyah \\ Komalah ${ }^{3}$, Devi Indah Masfufah ${ }^{2}$, Achmad Fadhoil $\mathbf{M z}^{3}$ \\ ${ }^{1}$ Fakultas Keguruan dan Ilmu Pendidikan, Universitas Islam Malang \\ ${ }^{2}$ Fakultas Ekonomi dan Bisnis, Universitas Islam Malang \\ ${ }^{3}$ Fakultas Pertanian, Universitas Islam Malang \\ *Korespondensi email: imron.azami@unisma.ac.id
}

\begin{abstract}
ABSTRAK
Covid-19 merupakan penyakit infeksi pernafasan yang dapat ditularkan melalui percikan batuk dan bersin. Masyarakat di sekitar kampungKebalen masih terlihat belum terbiasa menggunakan masker pada saat keluar rumah. Demikian juga upaya preventif pada saat keluar rumah, dengan menyediakan handsanitizer belum tercapai dengan baik dikarenakan harganya semakin meningkat tajam, serta melakukan penyemprotan agar kebersihan tetap terjaga. Tujuan dari pengabdian masayarakat ini adalah untuk memberdayakan masyarakat dalam penggunaan masker dan handsaitizer pada saat keluar rumah serta selalu menjaga kebersihan lingkungan sekitar. Metode pangabdian yaitu berupa donasi masker dan handsanitizer serta pemaparan cara pemakaiannya secara lisan, juga penyemprotan lingkungan sekitar. Hasil yang diperoleh adalah 5 orang sasaran sudah mendapatkan handsanitizer dan 5 orang mendapatkan masker dan 5 rumah yang telah dilakukan penyemrotan. Dengan demikian, masyarakat sekitar pada akhrinya dapat menggunakan masker dan perbekalan handsanitizer pada saat keluar rumah, dan lingkungan sekitar menjadi bersih.
\end{abstract}

Kata Kunci: masker; handsanitizer; penyemprotan; preventif; covid-19.

\section{PENDAHULUAN}

Coronavirus disease 2019 atau Covid-19 merupakan penyakit infeksi pernapasan akut yang disebabkan oleh coronavirus (SARS-CoV-2 yang pertama kali diidentifikasi pada akhir 2019 di kota Wuhan, Provinsi Hubei Cina (Beiu, Mihai, Popa, Cima, \& Popescu, 2020). Penyakit ini menyerang pernapasan dengan mudah, namun dalam beberapa penelitian, telah menemukan bahwa tingkat kematian pada wabah ini disebabkan oleh adanya penyakit penyerta seperti hipertensi diabetes mellitus, jantung koroner dan penyakit serebrovaskular (Fang, Karakiulakis, \& Roth, 2020).

Berdasarkan data dari World Health Organization (2020), Indonesia juga sudah mulai terpapar oleh virus corona sebanyak 172 orang dengan jumlah kematian sebanyak 55 orang per tanggal 17 Maret 2020. Perkembangan selanjutnya pada 31 Maret 2020, kasus ovid-19 meningkat menjadi 1.528 orang dengan jumlah kematian 136 orang (Setiati \& Azwar, 2020). Peningkatan kasus yang cukup tajam ini perlu dikendalikan bahkan harus dikurangi.

Upaya pencegahan terhadap peningkatan jumlah penderita Covid-19, seperti yang sudah ditetapkan oleh WHO pada bulan Maret 2020 bahwa semua negara didesak untuk melakukan langkah-langkah efektif untuk mengurangi penularan (Beiu et al., 2020). Oleh 
karena itu, tindakan pencegahan terhadap jenis penyakit menular tersebut wajib dilakukan secepat mungkin yang sesuai dengan Undang-Undang Nomor 6 Tahun 2018 yaitu tentang Kekarantinaan Kesehatan, dimana masyarakat perlu membatasi kegiatan social (Telaumbanua, 2020). Penyebaran pada masyarakat pun dapat dikurangi salah satunya dengan menjaga kebersihan tangan secara rutin (Beiu et al., 2020) dan upaya penggunaan masker (Greenhalgh, Schmid, Czypionka, Bassler, \& Gruer, 2020). Hal ini perlu dilakukan karena Covid-19 dapat dengan mudah ditularkan melalui jalur pernapasan (tetesan dari orang yang terinfeksi, melalui batuk atau bersin) dan melalui kontak dengan permukaan yang terkontaminasi. Seperti yang sudah dilakukan oleh masyarakat China, bahwa penggunaan masker sudah menjadi kewajiban yang harus diterapkan (Feng et al., 2020).

Keberadaan masyarakat di Kota Malang, khususnya dibeberapa tempat sekitar Kampung Kebalen, Kelurahan Kota Lama, Kecamatan Kedungkandang, Kota Malang masih terlihat belum seluruhnya melakukan upaya pencegahan tersebut. Hal ini juga mengakibatkan Kecamatan Kedungkandang menyumbang kasus Covid terbanyak di Kota Malang. Menurut data dari Pemerintah Kota Malang per 3 Agustus 2020, terdapat kasus ODP (Orang Dalam Pantauan) sebanyak 270, kasus PDP (Pasien Dalam Pengawasan) 173 dan yang positif terdampak covid 190 orang. Berdasarkan data tersebut, kami melakukan upaya pemberdayaan masyarakat untuk menggunakan handsanitizer dan masker serta penyemprotan sebagai upaya preventif bagi masyarakat terhadap peningkatan kasus Covid19.

\section{METODE}

Pengabdian masyarakat dilakukan pada hari Sabtu, 15 Agustus 2020 dengan menggunakan pendekatan penyuluhan one by one atau antar personal. Sasaran pengabdian masyarakat adalah masyarakat yang terdekat dengan kampung Kebalen Kota Malang. Tim membeli hand sanitizer di Alfamart. Pada pendistribusian hand sanitiser dan masker tim membagikan kepada warga sekaligus memberikan sedikit penyuluhan tentang penggunaan hand sanitizer dan masker, sedangkan penyemprotan dilakukan di halaman rumah masyarakat. Hal tersebut dilakukan oleh karenanya tidak boleh dilakukan secara berkerumun sebagai upaya social distancing guna kepentingan mencegah dari meluasnya covid-19 di masyarakat.

\section{HASIL DAN PEMBAHASAN}

Hasil pengabdian kepada masyarakat adalah tercapainya donasi handsanitizer dan maskser beserta pemaparan edukasi kepada masyarakat akan pentingnya menjaga kebersihan disekitar di wilayah terdekat dengan kampung Kebalen Kota Malang. Hasil capaian adalah jumlah sasaran yang sesuai target yaitu mendapatkan handsanitiser dan masker serta pemaparan kebersihan dengan penyemprotan desinfektan. Hasil capaian kegiatan pengabdian masyarakat dapat dilhat pada tabel.

Tabel 1. Hasil Capian Kegiatan Pengabdian Masyarakat

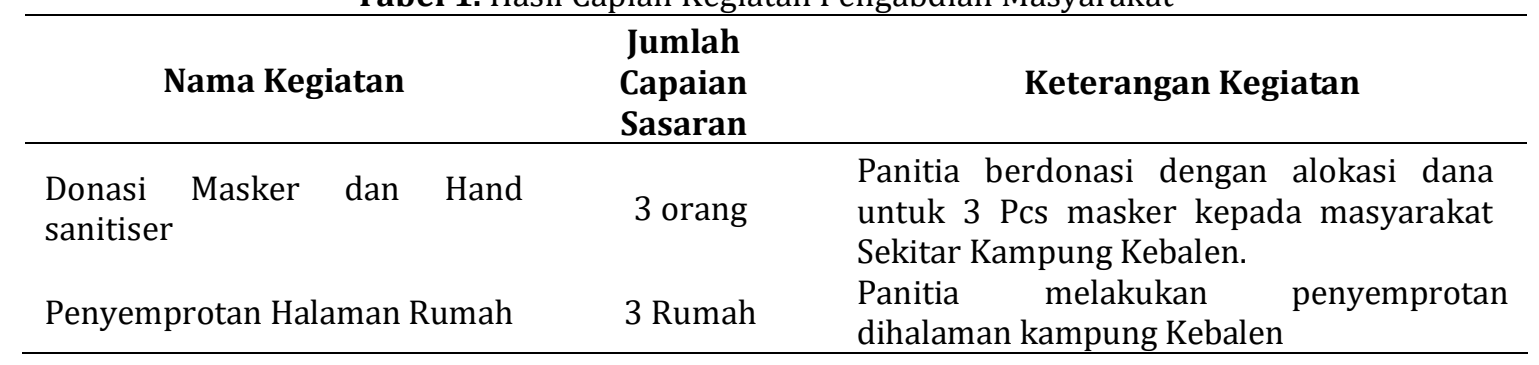


Kegiatan ini dilakukan oleh karena untuk meningkatkan pemahaman mengenai upaya preventif masyarakat terhadap pandemi Covid-19 sekarang ini, yaitu dengan cara membagikan handsanitzer dan masker, serta melakukan penyemprotan disinfektan. Masyarakat perlu mendapatkan pemaparan ilmu pengetahuan baik secara langsung maupun tidak langsung. Ilmu pengetahuan yang disampaikan adalah berupa edukasi secara lisan per orang dan tidak berkumpul oleh karena keterbatasan kami dalam proses penyampaian terutama akibat adanya pandemi Covid-19 ini.

Masyarakat di luar rumah di sekitar wilayah kampung kebalen, tidak semua yang menggunakan masker oleh karena tidak seluruhnya memahami betapa pentingnya menggunakan masker sebagai upaya preventif terhadap covid-19. Hal ini terbukti masih banyaknya masyarakat yang belum menggunakan masker sebagai pelindung diri dari bahaya Covid-19. Hal tersebut bisa dikarenakan informasi penggunaan masker yang pada awalnya belum diwajibkan oleh pemerintah di Wilayah kota Malang. Namun, seiringnya waktu berjalan, dan bertambahnya penderita Covid-19 maka dikeluarkan surat edaran mengenai kewajiban menggunakan masker.

Di sisi lain, pada saat keluar rumah juga tidak ada persiapan pemakaian handsanitiser jika suatu saat tangan dibutuhkan dalam kondisi bebas virus, seperti pada saat makan, pada saat memegang bahan makanan atau pada saat memilih bahan-bahan lainnya. Cara penggunaan hand sanitizer dipaparkan kepada masayarakat agar dilakukan hanya sewaktu waktu ketika berada di luar rumah. Pada saat di dalam rumah dianjurkan tetap mencuci tangan menggunakan sabun.dan menjaga kebersihan rumah sekitar demi mencegah penyebaran virus Covid-19.

Pada langkah awal, tim pengabdian masyarakat mendiskusikan dengan pihak dosen pembimbing lapangan untuk mengadakan pengabdian yang sangat dibutuhkan pada saat pandemi. Maka, berdasarkan hal tersebut disepakati untuk mengadakan bagi bagi masker dan handsanitizer kepada masyarakat kampung Kebalen.

Langkah kedua, tim melakukan pembelian masker dan hand sanitizer. Hal ini kami lakukan untuk mempermudah masyarakat mendapatkan handsanitizer. Langkah ketiga, tim melakukan pembagian Masker dan handsanitizer dan melakukan penyemprotan desinfektan. Pembagian dilakukan kepada warga sekitar kampung dengan pemaparan edukasi cara menggunakan handsanitizer yang baik dan benar.

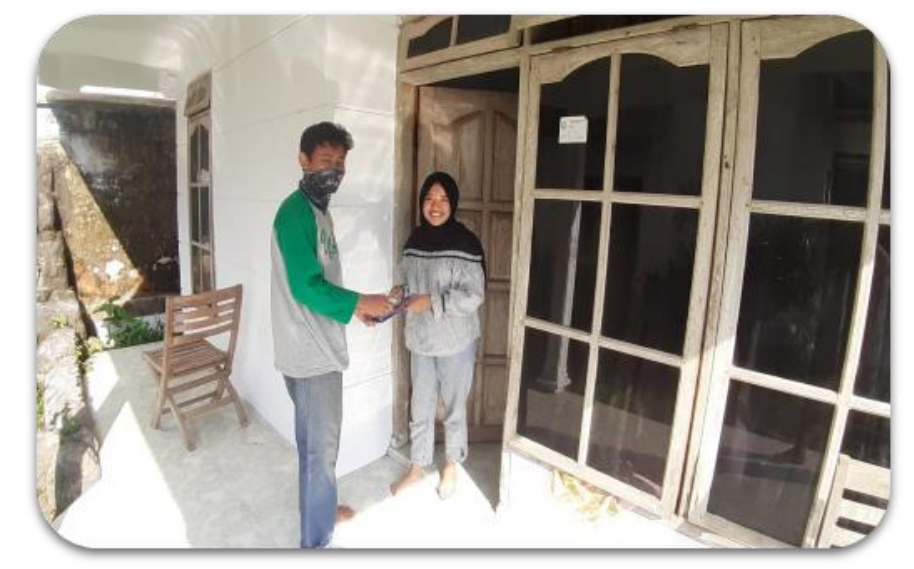

Gambar 1. Pembagian Masker dan Handsanitizer

Salah satu contoh tanaman yang dapat digunakan sebagai bahan dasar POC yaitu daun paitan. Daun paitan memiliki manfaat di antaranya yaitu mendukung pertumbuhan dan produksi tanaman, mampu mengurangi polutan dan menurunkan tingkat jerap $\mathrm{P}, \mathrm{Al}$ dan Fe aktif, Meningkatkan bobot segar tanaman karena mudah terdekomposisi, menyediakan 
nitrogen dan unsur hara bagi tanaman, melepaskan unsur NPK tersedia dan meningkatkan unsur P pada tanah.

Ada 2 cara dalam mengaplikasikan pupuk organik cair, yaitu dengan cara menyiram ke media tanam dan menyemprotkan secara langsung ke bagian daun. Selain diserap lewat akar, penyiraman memiliki tujuan untuk menghancurkan sisa pupuk kimia dalam tanah sehingga tanah menjadi gembur kembali. Sedangkan penyemprotan bertujuan agar pupuk cepat masuk ke dalam tanaman melalui lubang stomata pada daun, sehingga dapat digunakan langsung oleh tanaman. Pemberian pupuk baik penyemprotan atau penyiraman, akan lebih baik jika semua dosis tidak langsung diberikan.

Sering mencuci tangan dengan bahan kimia secara berkepanjangan dapat menyebabkan beberapa perubahan patofisiologis, seperti gangguan lapisan epidermal, gangguan keratinosit serta pelepasan sitokin proinflamasi. Efek dermatologis yang akan terjadi adalah kekeringan kulit yang berlebihan atau bahkan dermatitis sehingga disarankan kepada masyarakat untuk menjaga kondisi kulit dengan menerapkan pelembab segera setelah mencuci tangan atau setelah menggunakan pembersih tangan atau handsanitizer (Beiu et al., 2020).

Kegiatan selanjutnya adalah melakukan penyemprotan desinfektan dihalaman rumah warga sekitar kampung kebalen. Masker diupayakan langsung dipakai dan Handsanitizer dibawa saat berada d luar rumah. Seperti pada gambar 2.

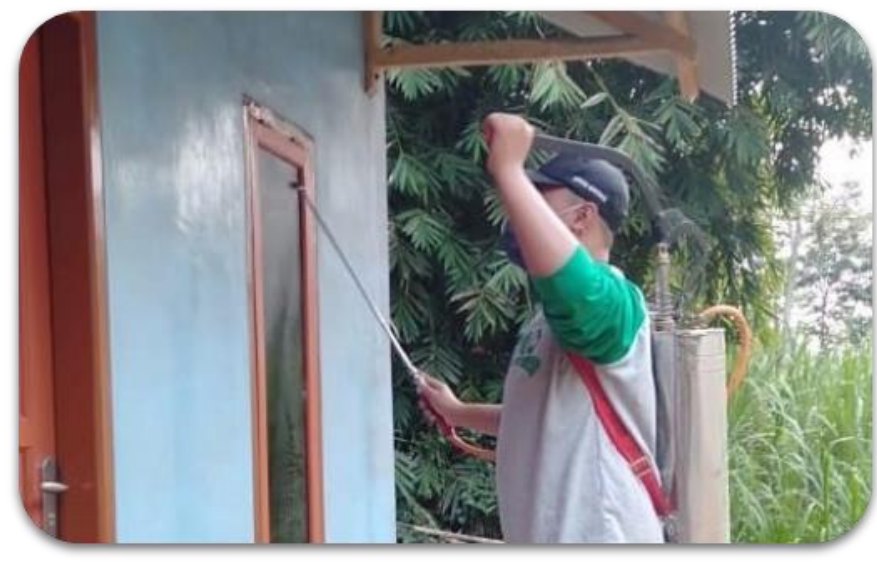

Gambar 2. Kegiatan Penyemprotan halaman sekitar rumah masyarakat kampung Kebalen

\section{KESIMPULAN}

Kegiatan pengabdian ini memberikan simpulan bahwa (a) pengabdian masyarakat telah tercapai target sasaran yaitu pemakaian masker dan handsanitiser disertai pemahaman pentingnya menjaga kebersihan lingkungan sekitar, serta (b) masyarakat memberikan respon yang sangat baik dengan indikator capaian yaitu mereka langsung memakai masker dan handsanitiser sesuai tujuan dan fungsinya.

\section{UCAPAN TERIMA KASIH}

Pada kesempatan ini Penulis mengucapkan terima kasih kepada semua warga masyarakat kampung Kebalen yang telah berpartisipasi dalam pengabdian ini.

\section{DAFTAR RUJUKAN}

Beiu, C., Mihai, M., Popa, L., Cima, L., \& Popescu, M. N. (2020). Frequent Hand Washing for COVID-19 Prevention Can Cause Hand Dermatitis: Management Tips. Cureus, 12(4). https://doi.org/10.7759/cureus.7506

Fang, L., Karakiulakis, G., \& Roth, M. (2020). Are patients with hypertension and diabetes 
mellitus at increased risk for COVID-19 infection? Lancet Respir Med, 8(4), 475-480. https://doi.org/10.1016/S2213-2600(20)30116-8

Feng, S., Shen, C., Xia, N., Song, W., Fan, M., \& Cowling, B. J. (2020). Rational use of face masks in the COVID-19 pandemic. The Lancet Respiratory Medicine, 8(5), 434-436. https://doi.org/10.1016/S2213-2600(20)30134-X

Greenhalgh, T., Schmid, M. B., Czypionka, T., Bassler, D., \& Gruer, L. (2020). Face masks for the public during the covid-19 crisis. The BMJ, 369(April), 1-4. https://doi.org/10.1136/bmj.m1435

Setiati, S., \& Azwar, M. K. (2020). COVID-19 and Indonesia. Acta Medica Indonesiana, 52(1), 84-89. Retrieved http://www.actamedindones.org/index.php/ijim/article/view/1426

Telaumbanua, D. (2020). Urgensi Pembentukan Aturan Terkait Pencegahan Covid-19 di Indonesia. QALAMUNA: Jurnal Pendidikan, Sosial, Dan Agama, 12(1), 59-70. https://doi.org/10.37680/qalamuna.v12i01.290

World Health Organization (WHO). Coronavirus disease (COVID-19) pandemic (2020). Retrieved from https://www.who.int/emergencies/diseases/novel-coronavirus2019 